\title{
Does Urban Agriculture help improve women`s resilience to poverty? Evidence from low- income generating women in Bulawayo
}

\author{
Nobuhle Sebata, Clifford Mabhena, Mkhokheli Sithole \\ Institute of Development Studies (IDS), National University of Science and Technology (NUST), Bulawayo, \\ Zimbabwe
}

\begin{abstract}
This article analyses how women have used Urban Agriculture (UA) as a resilience strategy to poverty in Bulawayo's high density suburb of Cowdray Park. Women, who are naturally the primary care givers tend to suffer the most in urban areas as quite often they have to bear the responsibility of food provision at home. The article focuses on how UA contributes to food security, employment, income and empowerment for women engaged in the practice. The research for this article is largely qualitative and uses primary data collected from 30 respondents using questionnaires, 5 key informant interviews, 2 focus group discussions and observations. Secondary data from government and non-governmental organisations documents was also used. The results indicate that UA contributes significantly to food availability and access for women engaged in the practice. However nutritional contribution is low and less diverse as farmers concentrate on growing maize than other crops. Income generation is also very low as women concentrate on subsistence production. This article further discusses the relative empowerment function of UA to women. It argues that despite problems encountered by women farmers such as marginalization of UA as a land use activity, shortage of water and lack of institutional support, UA still improved the socio- economic status and empowered urban women. The article therefore recommends that local authorities set aside land specifically for UA and provide institutional support such as sinking of boreholes and provision of inputs
\end{abstract}

Keywords: Urban agriculture, Food security, Empowerment

\section{Background}

Urban Agriculture is defined as the growing of plants and trees and rearing of livestock within or on the fringes of cities (intra-urban and peri urban agriculture, respectively), including related input provision, processing and marketing activities and services (Mougeot, 2006, Sithole et al, 2012). It is a dynamic concept that comprises a variety of livelihood systems ranging from subsistence production and processing at household level to fully commercialized agriculture. The greatest proportion of UA is undertaken as a survival strategy by individual households, generally in backyards, to augment household real income (Landon- Lane, 2004; Kekana, 2006; Reuther and Dewar, 2005).

Women's participation in and contribution to Urban Agriculture has been masked in past studies by reference to a so-called "urban farmer". This supposedly gender-neutral term suggests an undifferentiated urban dweller who engages in agriculture yet is undoubtedly based on a masculinised norm. However, recent studies document women's predominance in the African context (Cockram and Feldman, 1996; Smit, Ratta and Bernstein, 1996), and particularly in the Central African Republic (Alaruka and Choma, 1985), Kenya (Mwangi, 1998, Lee Smith and Memon, 1993, Mazingira Institute, 1987), Mozambique ( Loforte, 1987), Tanzania (Tripp, 1997; Mlozi, 1995), Uganda (Maxwell, 1995; Maxwell, 1994; Maxwell and Zziwa, 1990), Zambia (Drescher, 1997; Drescher and Bos, 1993; Rakodi, 1988), and Zimbabwe (Chaipa and King, 1997; Mudimu, 1996; Mbiba, 1995; Mbiba, 1993). Thailand (Evers and Korff, 1996), and the United States (Hynes, 1996) also points to the dominance of women farmers in urban areas. Women urban dwellers play pivotal roles in subsistence and market gardening, animal husbandry, food processing, waste recycling and (re)use.

The predominance of urban women farmers in many contexts is attributed to two factors: First, women continue to bear primary responsibility for household sustenance and well-being (Mudimu, 1996), largely due to traditional cultural views and societal expectations (Chaipa and King, 1997). Everyday domestic tasks, including the provision of food, water, clothing, and healthcare, as well as the maintenance of a clean homestead, fall to female household members who are responsible for biological and social reproduction. Second, women tend to have lower educational status than men thus face less probability in finding suitable wage employment in the formal sector (Streiffeler, 1993). Since few job opportunities exist for women in urban areas it becomes imperative for women to seek other ways to fill in the gap between cash income and what is needed and available for household reproduction (Rakodi, 1985). In combination, these two factors mean that 
women must often continue in their traditional reproductive roles and secure household subsistence through strategies that do not rely on formal employment.

Despite numerous studies on UA, in Zimbabwe most of these studies have failed to streamline gender issues (Mbiba (1994) on "Urban Agriculture in Zimbabwe: Implication for Urban Management", Smith et al. (1995), "Poverty and Urban poverty and urban agriculture: An overview of linkages in Harare", Mubvami (2006), "The Policy Framework and Practice of Urban Agriculture in Bulawayo", Mubvami and Manyati (2007), "HIV/AIDS, Urban Agriculture and Community Mobilisation: cases from Zimbabwe"; Kutiwa et al. (2010), "Urban Agriculture in Low Income Households of Harare: An Adaptive Response to Economic Crisis" and Sithole et al, (2012)). The dearth of data addressing the gendered nature of UA justifies this research. This article thus analyses the contribution of UA to food security as this tends to affect women more than men. We hypothesize that UA plays a significant role in income and employment generation while also empowering women in decision making at home. The article also attempts to highlight some of the specific challenges faced by women of Cowdray Park suburb as they pursue UA as a resilience strategy to economic hardships in Bulawayo.

\section{Materials and Methods}

The study was done in Cowdray Park high density suburb in Bulawayo. According to (Mpofu, 2011) the average number of people in each household in high density suburbs is 6 surviving on about US\$200 per month while the country's poverty line is US $\$ 400$. Estimates show that $80 \%$ of households in high density areas are food insecure.

The map in Figure 1 shows the location of Bulawayo in Zimbabwe as well as the study area, Cowdray Park, Ward 28, relative to other wards within the city.

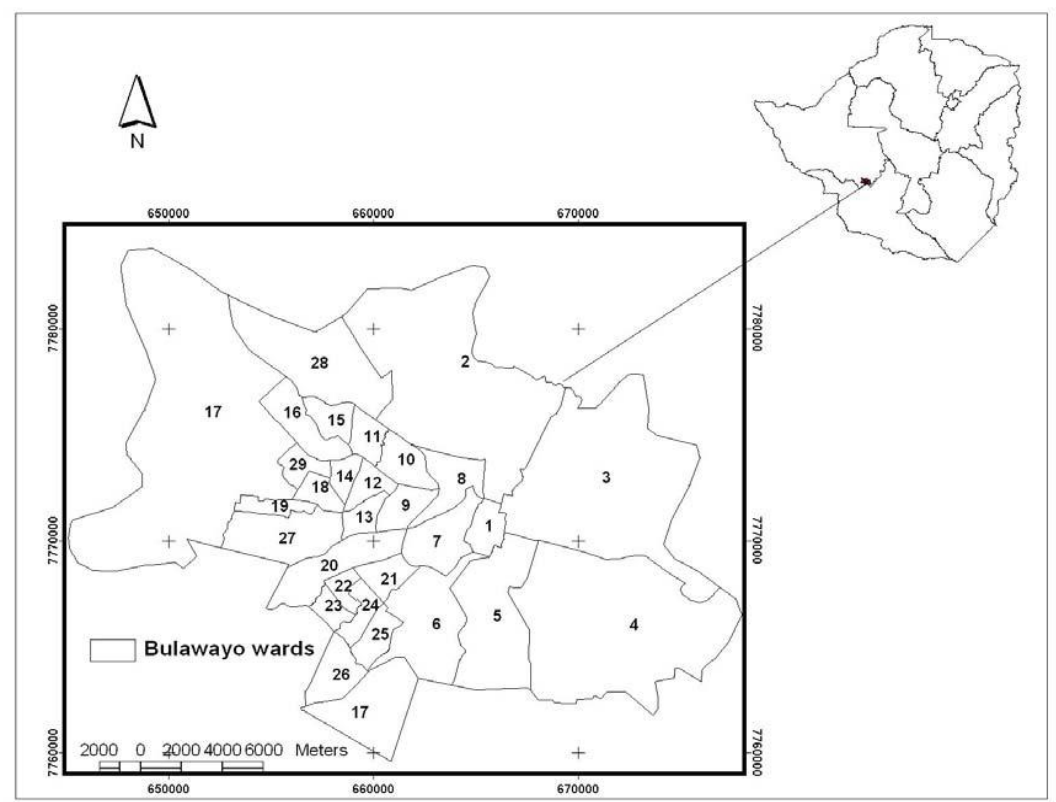

Figure 1 Map of Bulawayo Metropolitan and its wards. Cowdray Park is ward 28

Primary data was collected through 30 interviews using a structured questionnaire, 2 focus group discussions, and 6 key informant interviews. The 30 household heads (twenty women and ten men) were purposively identified through snowballing. This was done through identification of one urban farmer who later on identified other farmers who also identified others. The researchers were however aware that snowball sampling creates biases especially if the subjects are to be analysed in a quantitative environment. This is because the farmers who point other farmers are likely to be biased towards identifying their own friends unlike if the subjects were randomly sampled. However due to the fact that UA is not a formalized activity where farmers are registered by the authorities or where all urban residents are expected to practice, it is very difficult to identify them without prior knowledge. A sample size of 30 was thus considered reasonable by the researchers also because of the political environment as the country was preparing for parliamentary and presidential elections. People were reluctant to talk about other farmers. The key informants, purposively sampled, included the ward councillor for Cowdray Park (Ward, 28), the officials from the Bulawayo City Council and those from World Vision and also some of the urban farmers. 
Two focus group discussions were done, one with women and the other with men. Each focus group discussion had on average of eight participants. The separation was done to avoid male dominance thereby negatively affecting the flow of information, (Dwyer, 2001). Women in most communities in sub-Saharan Africa, for cultural and social reasons, have difficulties expressing themselves in the presence of men; quite often going along with views of men in fear of being labelled social misfits if they challenge men. However it is known that men and women have different life experiences due to their different roles often imbued differently across different societies (Helmore and Singh, 2001). Data collected included socio-economic characteristics, agricultural output, quantity sold, and access to credit, extension services, and distance to markets, food sufficiency, and crop consumption patterns challenges faced by women practicing UA.

\section{Results and Discussion}

The majority of the respondents were women compared to men (20 and 10 respectively). This could have been influenced by the fact that interviews were done during the day when the men were at work or out of the house. Most of the respondents fell between the 31 and 40 years with women dominating this category (see figure 3.1). Women also dominated in the age groups below 40 years and above 60 years.

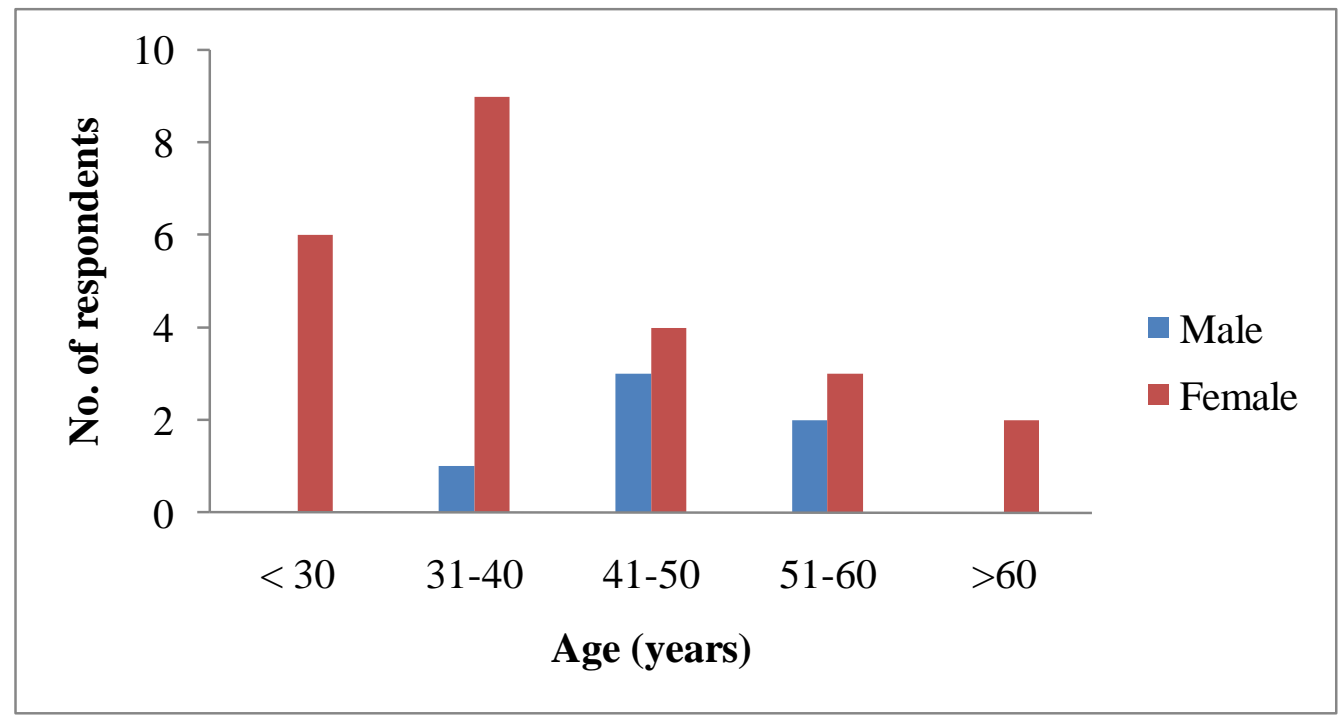

Figure 3.1 Age structure of sampled respondents in Cowdray Park

On education levels, male respondents dominated in tertiary education. The nature of education levels is very important in this study because it reveals that education is not a guarantee for securing employment.

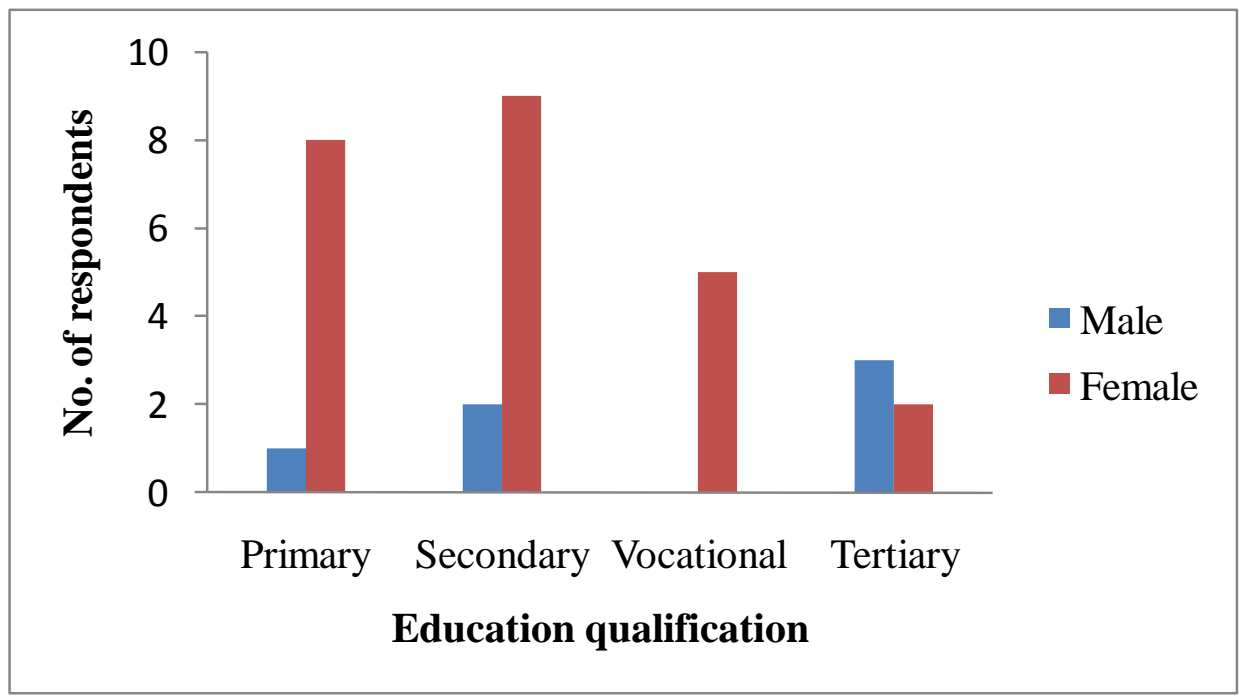

Figure 3.2 Education levels of the sampled household heads 


\subsection{Why women choose UA as a survival strategy}

Figure 3.3 shows the reasons why women engage in UA in the study area. The major reason stated was to supplement food at home (47\% of the respondents). Nutrition (23\%) and employment (20\%) also constituted significant reasons.

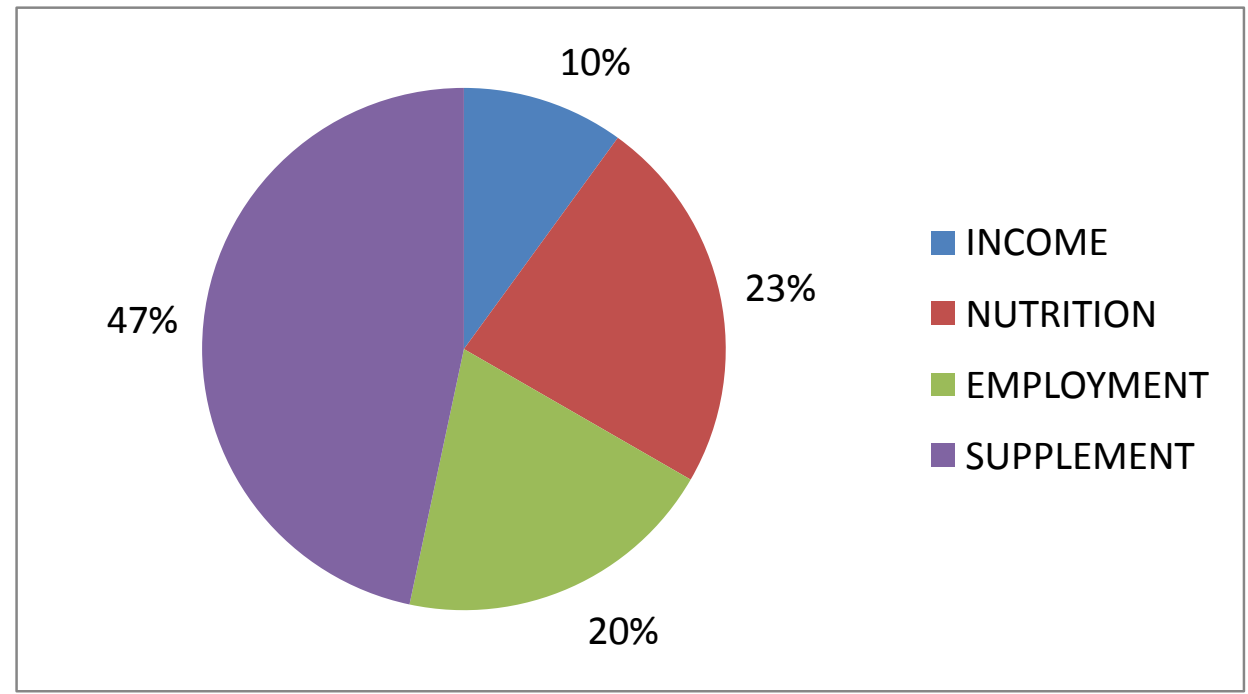

Figure 3.3 Reasons for engaging in UA in Cowdray Park high density Suburb

Urban agriculture is one of the main activities urban residents are undertaking in an effort to ensure food security and alleviate poverty. During one of the semi-structured interviews, one of the respondents had this to say:

I have 6 children of my own and 3 of my late sister. My husband is a teacher and earns a paltry USD 300. I have to do something lest my children starve. The easiest survival strategy is to farm because with my children there is enough labour to produce good quantities if it rains properly. Two years back we produced maize which helped us a lot in supplementing mealie meal at home. We didn't buy mealie meal for 2 months. (Married woman, 23/07/2013)

The councillor for ward Cowdray Park (Ward 28) also shared similar sentiments. He had this to say:

Since the late 1990s life began to drastically change in Bulawayo. Most industries closed because of poor business and many men were retrenched. Women had to do something that's why you see many of them doing a lot of farming on any piece of land they can get. I think many of them are really helping their families in providing food though everything depends on rainfall.(Ward 28 councilor, 22/07/ 2013)

On the other hand, married women and widows perhaps due to their reproductive roles of ensuring that the children have food at all costs dominate UA. During one of the focus group discussions, men unanimously, concluded that urban agriculture is a domain of married women and widows because output ends up in "their kitchen" as one respondent was quoted saying:

Married women do value urban agriculture as a source of fresh food to supplement what is bought from the market.(Male respondent, 22/07/2013).

Focus group discussion with men revealed that some women practice UA so that they at least get something to do since they are housewives hence regarded as not working. This gender bias however ignores other important roles that women do everyday such as raising children, cooking and generally taking care of everyone at home.

\subsection{Household Food Sufficiency from Own Production}

The period of time during which the produce of garden farming is sufficient for beneficiaries is an indication of its food or consumption gap. Observations show that the frequency of meals per day increased after harvesting implying high levels of self-sufficiency in carbohydrates notwithstanding poor rainy seasons resulting in water shortage, lack of inputs, skills and knowledge among the farmers (see figure 3.4 and 3.5). This shows the cultural importance of the contribution of staple crops in improving food security in Zimbabwe 
(Sithole et al, 2012). Despite having adequate cereals, households still need vegetables to augment their vitamin needs.

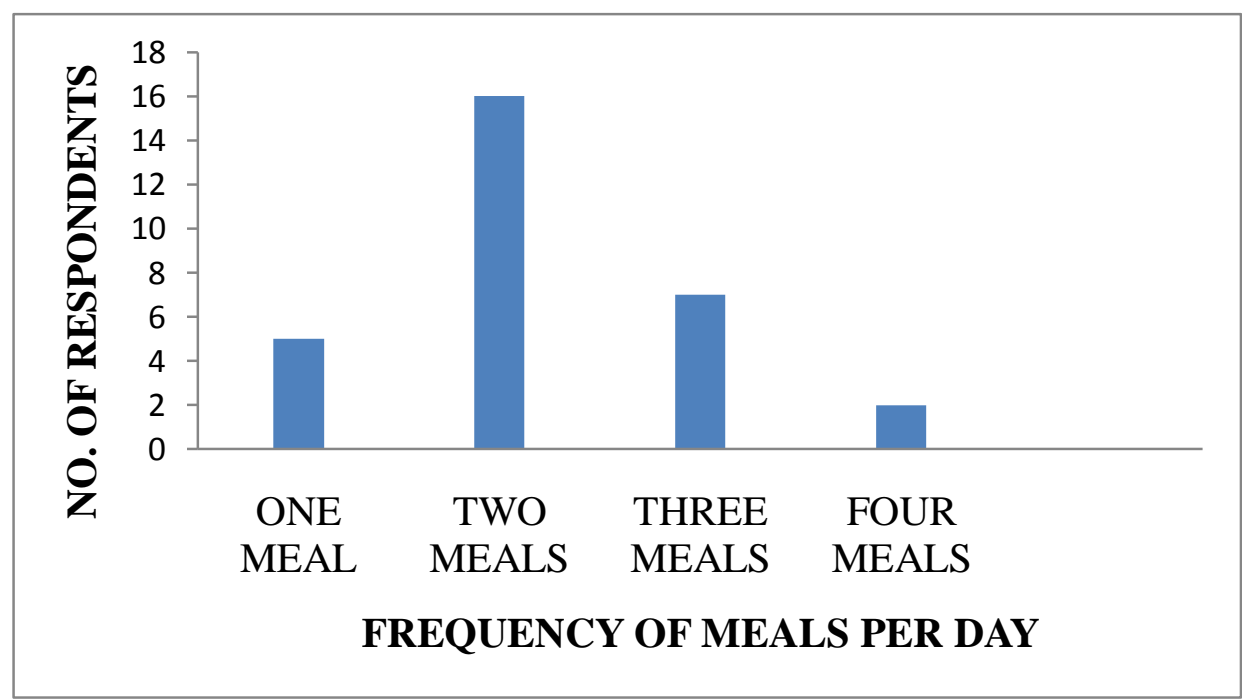

Figure 3.4 Frequency of meals per day before harvesting

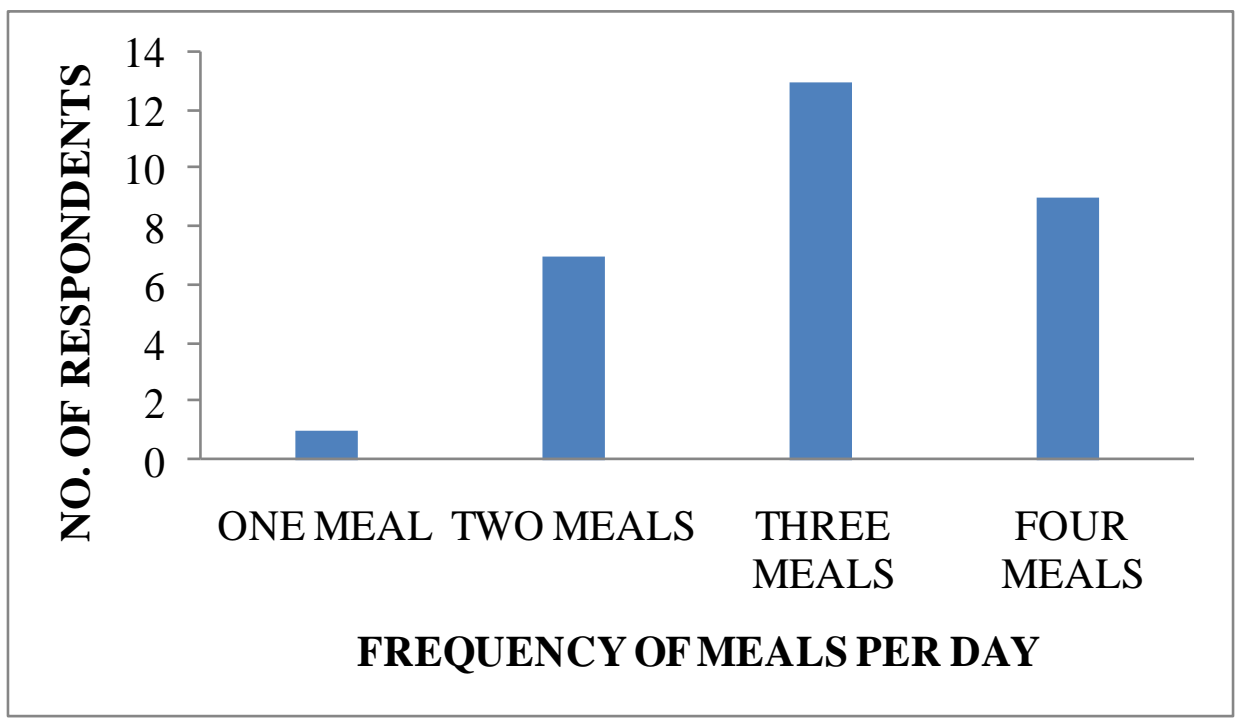

Figure 3.5 Frequency of meals per day after harvesting

In terms of food availability and access, it was noted that production is seasonal. People depend heavily on rainfall. Unlike other older suburbs, Cowdray Park does not have many boreholes that can be used for watering crops or vegetables. However, respondents reported that during good rainy seasons, harvests are good and this tends to change their frequency of meals as indicated in figure 3.4 and 3.5. Before harvests the majority of respondents usually have two meals per day compared to an average of three meals after harvest. It is important to note that the main crops grown are maize and sweet potatoes. Maize is usually allowed to dry and then crushed to produce mealie-meal which is a staple food for most people. Good harvests mean that there is more of mealie meal hence an increase in the frequency of meals per day. Sweet potatoes are either eaten alone or with tea. They are thus a good substitute for bread which is expensive for poor families. Bread costs US $\$ 1$.

\subsection{Nutrition}

It was very difficult to judge nutrition levels from field visits and from the respondents without a proper survey. The closest proxy that was used for this was from the type of crops grown with the assumption that these crops are also for own consumption. The pattern of mono cropping of maize gives an indication that the diet is largely made up of this crop. The current choice of crops is influenced by the cost of mealie meal which is expensive for many people. Five kilograms bag of mealie meal averages about US\$5 in the market at the moment, an amount which is very high for many poor households with large families. Maize is therefore preferred as it produces much needed mealie meal. Production of vegetables is limited to a few backyard gardens. Even the backyard gardens do not produce much because of water shedding in Bulawayo. 
A key informant from World Vision, who happens to be a nutritionist, had this to say:

Urban Agriculture in Cowdray Park is biased towards maize production which depends on rainfall. Water shedding and few water supplies like boreholes mean that there is no variety of crops grown. Vegetables are scarce in this suburb and this compromises the nutrition of food consumed from UA in this ward. There is a need to improve on water sources so that people can at least grow and eat fresh healthy vegetables that are good for one`s health, instead of buying these all the time. (World Vision nutritionist, 24/07 2013)

\subsection{Contribution of UA to employment and income generation}

The study revealed that UA provides some form of employment which is combined with women`s roles at home. One of the women respondents in a FGD session argued that:

Farming is our employment. Although we do it seasonal and don't make much money, we feel UA is some form of employment that benefits us a lot through food supplementation (Female respondent, 25/07/2013).

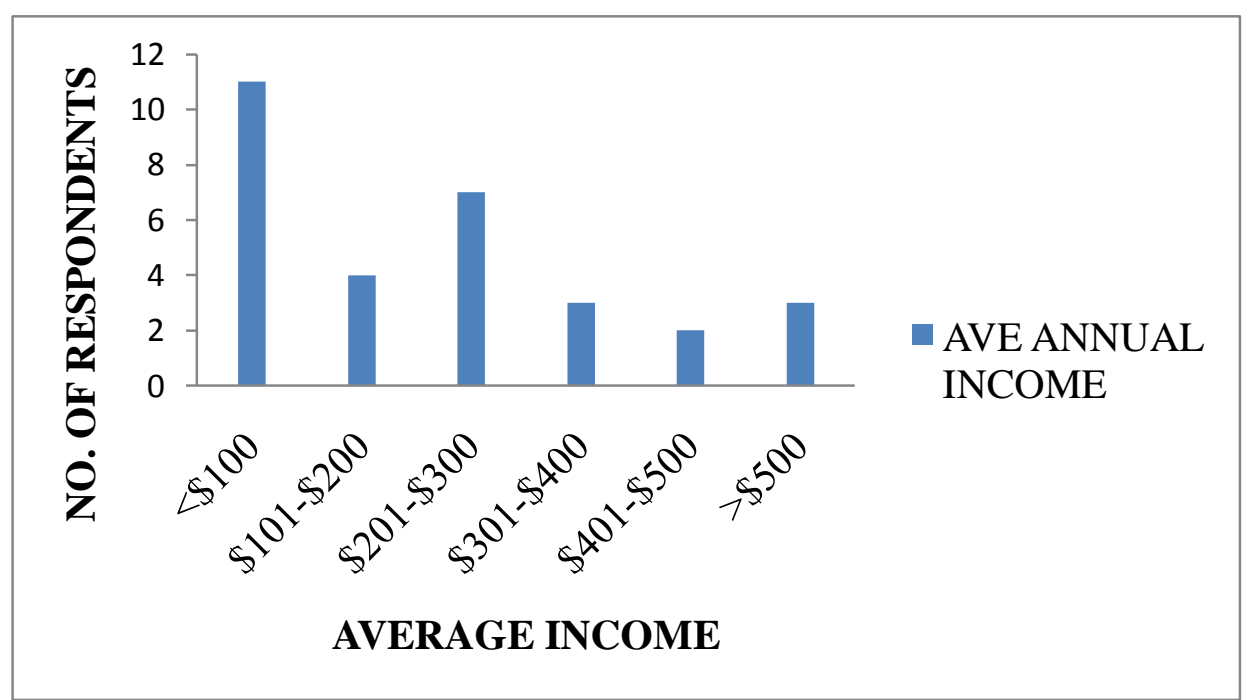

Figure 3.6 Average annual incomes from sale of UA produce in Cowdray Park high density Suburb

Figure 3.6 indicates that not much is realised from the sale of UA produce. For those who sell their produce, the majority (about 11 respondents) make less than US\$100 annually. Only about 3 respondents make above US\$500 from selling their produce.

\subsection{Contribution of Urban Agriculture to Women's Socio- economic Empowerment}

Table 1 summarises the decision- making in Urban Agriculture as influenced by husband or wives in the households. In this article, the term empowerment is used to mean the extent to which women can have access to or control over family resources, participate in decision- making, and contribute to the family's welfare. Findings from the study indicate that women are in a better position to make decisions because of UA. Table 1 indicates that decisions whether to cultivate or not are made and controlled by women. Out of 20 women interviewed, 15 of them acknowledged that they are responsible for deciding whether to practice UA or not. This constitutes $75 \%$ of all the respondents. Although women should not be generalised as a homogeneous group due to their differences based on socio-economic status, decision-making concerning UA seem to cut across these distinctions.

Table 1 Decision- making in Urban Agriculture as influenced by husband or wives in the households.

\begin{tabular}{|c|c|c|c|c|}
\hline \multirow{2}{*}{ Decision maker } & \multicolumn{2}{|c|}{ Men } & \multicolumn{2}{|c|}{ Women } \\
\cline { 2 - 5 } & Freq & Freq. & \% \\
\hline Husband/Man & 5 & 16.6 & 3 & 15 \\
\hline Wife/Women & 2 & 6.6 & 1 & 5 \\
\hline Both of the above & 2 & 6.6 & 1 & 5 \\
\hline Others & 1 & 3.3 & 0 & 0 \\
\hline None Response & 0 & 0 & 20 & 100 \\
\hline Total & 10 & 33.1 & 15 & 5 \\
\hline
\end{tabular}

This makes it clear that urban agriculture increases women's contribution to the livelihood of their families, which is an indicator of their socio-economic empowerment. By virtue of giving women capacity to contribute to household food requirements, urban agriculture is an important strategy to empower them socially. 
Table 2 summarises the effects of decision making for women before and after practising UA. Before UA only 2 out of 20 women respondents stated that they influenced that decision. However after engagement in UA, about 17 out of 20 had the power to influence that decision. Women did not have much influence on other key socioeconomic activities such as Child Education which remained strongly controlled by men as shown in table 2 . This is because women are engaged in UA to supplement food at home. They rarely generate much income as is shown in figure 3.6 where the majority of respondents make less than US $\$ 100$ per year.

Table 2 Decision making for women before and after practising UA

\begin{tabular}{|c|c|c|c|c|}
\hline \multirow[t]{2}{*}{ Activity } & \multicolumn{2}{|c|}{ Before } & \multicolumn{2}{|c|}{ After } \\
\hline & Yes & No & Yes & No \\
\hline Child Education & 7 & 13 & 15 & 5 \\
\hline $\begin{array}{l}\text { Provision Household food } \\
\text { Requirements }\end{array}$ & 2 & 18 & 17 & 3 \\
\hline Buying Agricultural Inputs & 10 & 10 & 12 & 8 \\
\hline Buying Personal Items & 9 & 11 & 11 & 9 \\
\hline
\end{tabular}

This however is in contrast to women who are engaged in garden farming in other suburbs of Bulawayo. Sithole et al, (2012) noted that income estimates from the sale of fresh vegetables by women were relatively higher than earnings of civil servants in the same period.

\subsection{Problems faced by Urban Women Farmers}

Figure 3.7 summarises the challenges faced by women who engaged in UA in Cowdray Park high density Suburb. The major challenges faced by women who engaged in UA in Cowdray Park were access to land and water (see figure 3.7). Most of the land is owned by the city council as it was indicated by the respondents in one of the questions in the questionnaire hence this poses a problem for the farmers due to the policies and regulations that change and sometimes people can be chased off from the land that they are cultivating and in some instances building projects are done on areas where people are cultivating and people are not notified of such developments.

Many researchers have identified, in general terms, women's lack of access to land as a major constraint to urban agriculture activities (Maxwell et al., 1998; Smit et al., 1996; Maxwell, 1995; May and Rogerson, 1995; Maxwell, 1994; Drescher and Bos, 1993; Haile, 1991; Matlala, 1990).

Women in many countries have been, and continue to be, barred from claiming ownership of land plots due to cultural traditions. Moreover, deflated economic status, and difficulties faced within the formal employment sector preclude women's ability to purchase land in their own right. Thus women tend to rent, borrow, or illegally use land for urban agriculture activities. Some urban farmers are not aware that urban farming is illegal especially on public land, while those who are aware lack legal authority to engage in the practice; or take advantage of the laxity of law enforcement by city administration. The major problem to urban women farmers is therefore that they are not sure when these places will be given out to urban developers. In most cases when the land is bought, farmers are given a very short notice to leave and that leads to loss of substantial amounts of capital and labour invested in urban agriculture.

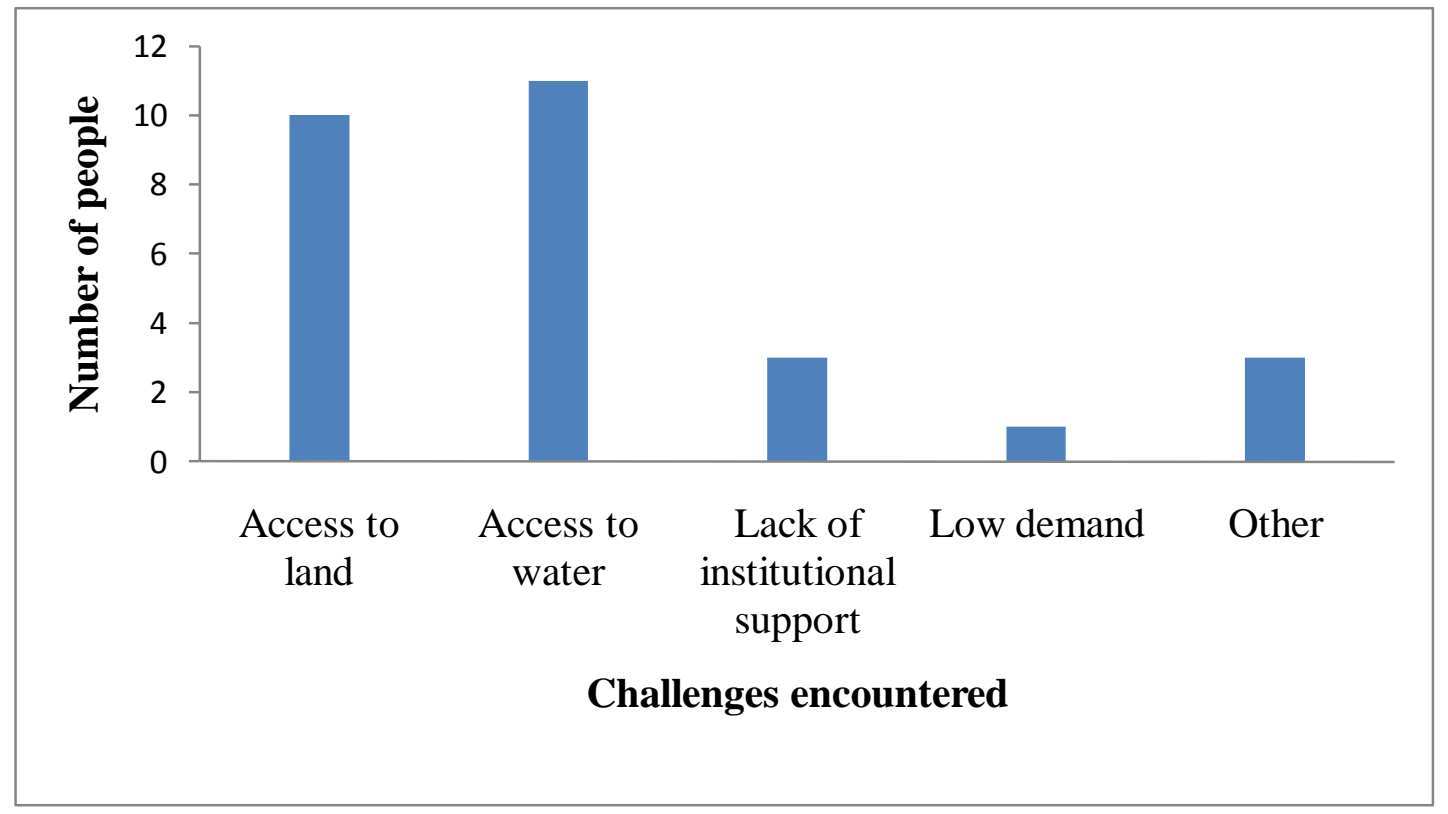

Figure 3.7 Challenges faced by women engaged in UA 
For example, Cowdray Park is still a growing suburb with a lot of land still being cleared for construction of more houses and business buildings such as the Garikai /Hlalani Kuhle housing project. This results in reduction of agricultural land. Farmers sometimes have to go too far away areas in search of unused pieces of land to cultivate, though temporal. The study revealed that though women have access to public land, when the Bulawayo City Council claims or sells the land, the farmers are ruthlessly thrown out. This means that urban farming is carried out and survives under hostile conditions and the law does not protect the farmers since the policies that govern urban agriculture in the country are not strict. Therefore women are not sure whether to invest in much since this is an unpredictable sector. When urban agricultural land is allocated to developers, they are given a short notice to vacate their gardens and this means loss of substantial amounts of capital and labour invested in urban agriculture. Therefore women are not certain when these "so- called" vacant areas will be given to urban farmers. In other words, UA competes with other land- utilizing activities like residences, commerce and industrial construction. However, in most areas UA is not considered a major land- use activity. Access to water, for example, is a key constraint to productive capacity and successful farming is often limited to the rainy season. Bulawayo is in a dry part of the country and water shortages are common. The majority of the respondents also argued that they were not getting enough support from institutions such as the government and NGOs.

Lack of institutional support also affects women practising urban agriculture. Although World Vision has done a lot in trying to support them, without government and city council intervention the projects suffer. Urban agriculture is currently an informal sector activity in Zimbabwe although the policy framework for the development of UA is slowly starting to be supportive of the activity. Most literature on urban agriculture reflects the negative publicity it has received where those involved have been severely discouraged and punished. This has been due to arguments by city council authorities that the uncontrolled encroachment of traditional' cultivation practices upon environmentally sensitive land and the ill-advised use of chemicals in vegetables and crop production has many ills.

\subsection{Conclusion}

From the above discussion of results this article concludes that UA can be a resilience mechanism for women in low income households. It is important in supplementing food at home hence it plays a key role in mitigating problems of food shortages. Women find it easy to practice UA because it is for free and has immediate returns. However, because the type of UA practised in Cowdray Park depends on natural rainfall, production tends to be seasonal hence not much is produced for sale. Most of the food produced by women is for home consumption.

Analysis and discussion of results showed that UA has empowered women to influence decisions at home. Most of those interviewed argued that they are now listened to by their husbands because they are also bringing food at home. Involvement in UA makes women in Cowdray Park agents of change. Gone are the days when they would sit around and expect their men to bring food to the house. Through UA they are also contributing to food provision. The findings however reveal that even though women have been empowered to make decisions at home, their gender roles at home are still not considered as work. Women find themselves doing double roles of taking care of their homes and farming.

\section{Acknowledgements}

The authors would like to acknowledge contributions from various reviewers of various drafts of this paper particularly colleagues at the Institute of Development Studies of the National University of Science and Technology (NUST) in Bulawayo and at the Centre for Development Research at the University of Natural Resources and Life Sciences (BOKU) in Vienna. We are grateful to the support received from the various institutions and individuals during the conducting of this research particularly the councillors, council staff and the farmers. However the views expressed in this document are those of the authors and not of the various institutions mentioned in this document.

\section{References}

[1]. Alaruka, A. A., and Choma, N. K. (1985). Les femmes de Kisangani et la pratiqueagricole. Annales de l'InstitutSupérieurPédagogique de Kisangani.(Etudes Série A) 14:83-95.

[2]. Chaipa, I. and King B. (1997). Urban Agriculture in Gweru: Household Nutrition, Economic Costs and Benefits. IDRC Project No. 01015. Harare: Research, Development and Consultancy Division of Environment and Development Activities-Zimbabwe (ENDAZimbabwe).

[3]. Cockram, M and Feldman S. (1996). The beautiful city: gardens in third world cities. African Urban Quarterly.

[4]. Drescher, A. W. (1997). Management strategies in African homegardens and the need for new extension approaches. Paper presented at the International Conference on Sustainable Urban Food Systems. Ryerson Polytechnic University. Toronto, Canada. 22-25 May 1997

[5]. Drescher, Axel W. and Bos F. (1993). Report on fieldwork on homegardening in Northwestern Province (Zambia)". Household Food Security, Nutrition and Health Monitoring Report. Lusaka, Zambia: Central Statistical Office.

[6]. Evers, H. and Korff, R. (1996).Subsistence production in Bangkok. Development: Seeds of Change 4:50-55. 
[7]. Haile, F. (1991).Women fuelwood carriers in Addis Ababa and the periurban forest. Report to the International Development Research Centre (IDRC) and National Urban Planning Institute (NUPI). Geneva: International Labour Organization.

[8]. Helmore, K., and Singh, N., 2001. Sustainable Livelihoods: Building on the Wealth of the Poor. Kumarian Press, Bloomfield CT, USA.

[9]. Hynes, H. P. (1996). Why so many women? H. Patricia Hynes (ed). A Patch of Eden: America's Inner-City Gardeners. Vermont: Chelsea Green Publishing Company.

[10]. Kekana, D.S. (2006). A socio - economic analysis of urban agriculture: The Soshanguve Project Case Study. Unpublished M.A. thesis.University of Pretoria.

[11]. Landon-Lane, C. (2004). Diversifying Rural Incomes through Home Gardens. Rome: FAO.

[12]. Loforte, Ana Maria. (1987). Migrantes e suaRelaçao com o Meo Rural.Trabalhos de Arqueologia e Antropologia4:55-60.

[13]. Matlala, Padi. (1990). Mamelodi's amazing maize growers.New Ground 1(1):30-31.

[14]. Maxwell, J.A. (1996). "Qualitative Research Design: An Interactive Approach.” Applied Social Research Methods Series. Vol. 41. Sage Publications, Thousand Oaks, London.

[15]. Maxwell, D. G. (1995). "Alternative food security strategy: a household analysis of urban agriculture in Kampala." World Development, 23 (10). pp. 1669-1681.

[16]. Maxwell, D. and Zziwa, S. (1993). Urban agriculture in Kampala: indigenous adaptive response to the economic crisis. Ecology of Food and Nutrition 29:91-109.

[17]. Maxwell, D. G., Levin, C., and Csete, J. (1998). "Does urban agriculture help to prevent malnutrition? Evidence from Kampala." FCND Discussion, paper 43, Washington DC

[18]. May, J. and Rogerson C.M (1995). "Poverty and sustainable cities in South Africa: the role of urban cultivation". Habitat International. 19(2): 165-181.

[19]. Mazingira Institute. (1987). Urban Food Production and the Cooking Fuel Situation in Urban Kenya. Nairobi: Mazingira Institute.

[20]. Mbiba B. (1995). Urban Agriculture in Zimbabwe, Implications for urban management and poverty, Ashgate publishing limited, England.

[21]. Mbiba, B. (1993). Urban agriculture, the poor and planners: Harare case study. Inter-Schools Conference. United Kingdom: Development Planning Unit at the University College London. 129-135.

[22]. Mlozi, M. R.S. (1995). Information and the Problems of Urban Agriculture in Tanzania: Intentions and Realizations.PhD Thesis.Department of Educational Studies.University of British Columbia.

[23]. Mougeot, L.J.A. (1994). "Leading Urban Agriculture into the 21st Century: Renewed Institutional Interest" in A. G. Egziabher, D. Lee-Smith, D.G. Maxwell, P.A. Memon, L.J.A. Mougeot and C.J. Sawio (eds) Cities Feeding People Ottawa: IDRC

[24]. Mougeot, L.A. (2006), Growing Better Cities: Urban Agriculture for Sustainable Development, IDRC.

[25]. Mpofu, B. (2011). 'Some Perceptions on the Poverty Question in Zimbabwe', 16 September, Solidarity Peace Trust. Online;http://www.solidaritypeacetrust.org/1109/some-perceptions-on-the-poverty-question-in-zimbabwe/. (13/03/2012).

[26]. Mudimu, G. (1996). "Urban agriculture activities and women's strategies in sustaining family livelihoods in Harare, Zimbabwe."Singapore Journal of Tropical Geography. 17 (2): 179-194.

[27]. Mubvami, T. and Manyati, M. (2007). "HIV/Aids, Urban Agriculture and Community Mobilisation: cases from Zimbabwe." UA magazine 18.

[28]. Mubvami, T. (2006). “The Policy Framework and Practice of Urban Agriculture in Bulawayo".UA magazine

[29]. Mwangi, A. and Foeken, D. (1998). "Farming in the city of Nairobi." African Studies Centre Netherlands.

[30]. Rakodi, C. (1985). "Self reliance or survival? Food production in African cities with particular reference to Lusaka" Africa Urban Studies, Number 21 pp 53-63

[31]. Rakodi, C. (1988). "Urban agriculture: Research Questions and Zambian Evidence.” The Journal of Modern African Studies, Vol. 26.No. 3.

[32]. Reuther S, and Dewar N (2005) Competition for the use of public open spaces in low income areas: The economic potential of urban gardening in Khayelitsha, Cape Town. Dev. Southern Afr., 23(1): 97-122.

[33]. Sachikonye, L.M. (2005). The Promised Land: From expropriation to reconciliation and Jambanja. Weaver Press, Harare.

[34]. Sithole, M; Nkala, P and Dube, N (2012). Do Urban Community Gardens Matter? : The Case of Bulawayo Metropolitan Province in Zimbabwe. Mediterranean Journal of Social Sciences, Vol. 3 (9), PP 249-257.

[35]. Smit, J. Ratta, A. and Bernstein, J. (1996). Urban agriculture: an opportunity for environmentally sustainable development in subSaharan Africa. Post-UNCED Series. Paper No. 11. The World Bank, Environmentally Sustainable Division and Africa Technical Department.

[36]. Smith, James R. (2003). "Poverty, Power and Resistance: Food Security and Sovereignty in Southern Africa." Innogen Working Paper 6.

[37]. Smith D, Bowyer-Bower, T, and Tevera, D (1995) Urban poverty and urban agriculture: An overview of the linkages in Harare. Habitat International. Volume 19, Issue 2, Pages 183-193

[38]. Streiffeler, F. (1993). General Principles and Approaches for Sustainable Urban Greenbelts with Special Reference to Africa. Berlin.

[39]. Tripp, A. M. (1997). Changing the Rules: The Politics of Liberalization and the Urban Informal Economy in Tanzania. Berkeley \& Los Angeles: University of California Press. 